\title{
CLIMATOLOGY OF HAIL IN CENTRAL EUROPE
}

\author{
Katarzyna SuwaŁa, Ewa Bednorz \\ Institute of Physical Geography and Environmental Planning, Adam Mickiewicz University in Poznań, Poland
}

Manuscrip received: May 8, 2013

Revised version: July 17, 2013

Suwata, K., Bednorz, E., 2013. Climatology of hail in central Europe. Quaestiones Geographicae 32(3), Bogucki Wydawnictwo Naukowe, Poznań, pp. 99-110. 2 tables, 6 figs. DOI 10.2478/quageo-2013-0025, ISSN 0137-477X.

AвSTRACT. Taking into consideration the spatial variability of the occurrence of hail in central Europe in the warm season (April - September) during the years 1966-2010, five hail regions were distinguished by Ward's group hierarchy method. For this purpose the daily data of hail occurrence were used. Circulation patterns responsible for hail precipitation at each cluster of stations were analysed using Reanalysis data (NCEP/NCAR). Composite maps of the sea-level pressure, $500 \mathrm{hPa}$ geopotential height and $850 \mathrm{hPa}$-level temperature means were constructed for the days with hail. Additionally, anomalies of the values of each parameter were presented. It was found that more than $65 \%$ of hail events were recorded from April to June, with May as the hail-peak month. In all five distinguished regions hail precipitation was associated with negative anomalies of SLP and $500 \mathrm{hPa}$ heights over Europe, most often with low-pressure systems developing within colder than usual air mass.

KEY WORDS: central Europe, hail frequency, hail regions, atmospheric circulation

Address of the corresponding author: Ewa Bednorz, Institute of Physical Geography and Environmental Planning, Adam Mickiewicz University in Poznań, ul. Dzięgielowa 27, 61-680 Poznań, Poland, e-mail: ewabedno@amu.edu.pl

\section{Introduction}

In many countries, hailstorms are considered to be among the most costly hazards, despite the small scale of this phenomenon. According to Changnon et al. (2009), average annual hail losses in the USA are $\$ 852$ million for property and \$581 million for crops, with a national total of $\$ 1.433$ billion. During the last 100 years in Australia, this phenomenon was responsible for $11 \%$ of building damage, just after tornado cyclones, floods and bushfires (Leigh 2007). Hail is not only extremely destructive but also, what makes matter worse, it is difficult to predict or estimate its occurrence in non-urban areas, where weather observations are less dense (Leigh 2007, Kunz et al. 2009). Factors that may cause hail include: the instability of the atmosphere, strong wind shear, convective activity, higher than average minimum air temperature, the height of freezing level and geographical features (Niall, Walsh 2005). The terrain influence on hail occurrence is most often neglected, though it is the topography that modifies the heat transport and triggers forced convection, which may result in serious destructions in natural environment (Hohl et al. 2002, Changnon et al. 2009).

The study area (particularly Poland) was chosen mainly due to the insufficiency of studies and information concerning hail, especially referring to the large-scale circulation conditions. In previous studies the general characteristics of hail in central Europe have been presented such as spatial and temporal vari- 
ability with a few case studies on the most severe events (Koźmiński 1964, Groenmeijer, van Delden 2006, Kunz et al. 2009, Bielec-Bąkowska 2010). Southern and northern parts of Europe were more thoroughly examined with respect to hail, giving a comprehensive picture of its occurrence, usually considering synoptic factors (Svabik 1989, Simeonov, Georgiev 2003, Sioutas, Flocas 2003, Piani et al. 2005, Sioutas et al. 2009, Tuovinen et al. 2009). Most of the studies concerning hail occurrence associated with atmospheric circulation are based on large-scale circulation classification by Hess-Brezowsky (Kunz et al. 2009) or Niedźwiedź (Bielec-Bąkowska 2010). Special attention should be paid to those studies, in which the authors developed their own synoptic or large-scale circulation patterns related to the specific conditions of hail occurrence in their region. Typically they are based on weather maps or reanalysis data of geopotential heights, lapse rate, precipitable water or relative humidity (Simeonov, Georgiev 2003, Sioutas, Flocas 2003, Piani et al. 2005). Kapsch et al. (2009), for instance, used the objective weather classification method to identify hail from largescale weather patterns, for which purpose the ERA-40 reanalysis data were applied. In recent years, more attention has been paid to the use of sounding-derived parameters such as CAPE (Convective Available Potential Energy), vertical wind shear or SRH (storm-relative helicity), (Groenmeijer, van Delden 2006) which leaves room for further research. Another reason for examining hail is the fact that it still raises many concerns as being frequently mistaken with other ice precipitation such as graupel or ice pallets.

The subject of this study can be divided into few sections. Firstly, to give the climatological background of hail in this part of Europe, the spatial and seasonal distribution of hail frequency was examined. Secondly, hail regions in central Europe were distinguished, in order to organise further analysis. The main objective, though, is to determine the baric and thermal conditions causing hail in this part of Europe, which will complement the scientific research into extreme weather events.

\section{Data and methods}

The first step of this analysis was to select 65 stations, located in Poland (33 stations) and Germany (32 stations), which represent the central part of Europe (Fig. 1). The limitation of the research area only to those two countries was due to the lack of complete and correct data series for such a long period of observations, as vast majority of them cover no more than 15 years.

Most of the stations are located at an elevation below $1000 \mathrm{~m}$. The only exceptions are Feldberg (1490 m) and Wendelstein (1832 m), which were used for this analysis owing to the high frequency of hail. Many stations were chosen deliberately due to their geographical location as there is a strong relationship between hail formation and topography, the distance from water reservoirs or the type of land covering (Kunz et al. 2009, Changnon et al. 2009). The elevation of the research area increases to the south from vast lowlands and lake districts reaching the North Sea and Baltic Sea in the northern part to the uplands and low mountains such as the Swabian and Franconian Jura. Thus, the latitudinal gradient in topography creates specific conditions for air mass movements, which usually reach the area of central Europe from the western sector.

This study was based on two kinds of data, both of which covered the warm season (from April to September) during the years 1966-2010. Firstly, the daily data of hail occurrence (days with hail) derived from the Institute of Meteorology and Water Management (IMGW PIB) and Deutscher Wetterdienst databases were used to present the general characteristics of hail in this part of Europe and to distinguish hail regions in this part of Europe.

The regionalisation was necessary because of the size of the study area and, consequently, the differences in the weather and climatic conditions, such as air temperature, direction of air mass influx, or the continentality/maritimity of climate. As a result, the analysed sector of central Europe was divided into smaller regions, characterised by similar seasonal hail variability within each of them. Afterwards, the Ward's method of hierarchical clustering was used. This method is a hierarchical agglomerative cluster technique based on Squared Euclidean Distances which is 


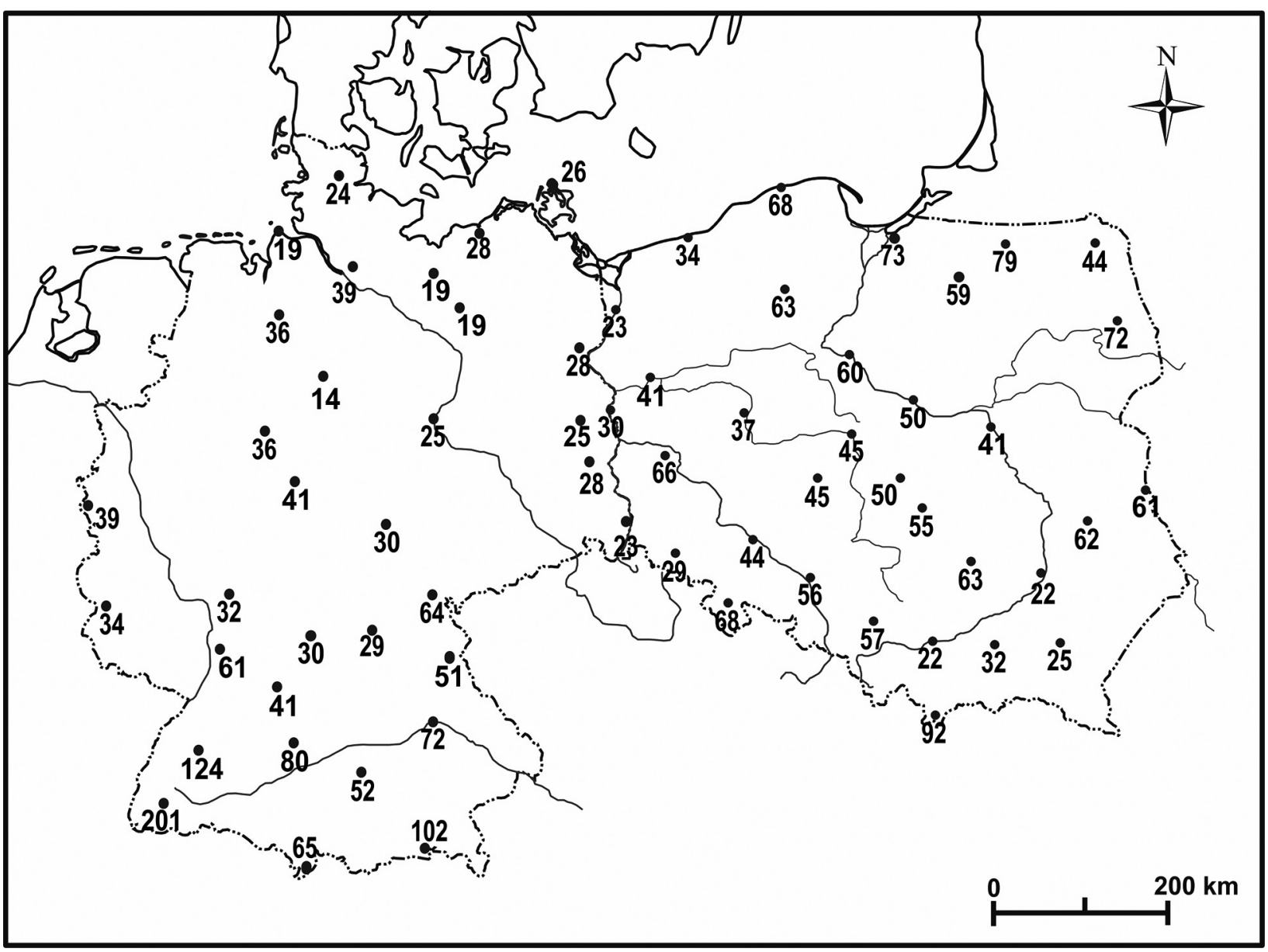

Fig. 1. Number of days with hail during the warm half-year 1966-2010

appropriate for analyses where the number of clusters is unknown and where samples are relatively small. The aim of using this cluster analysis was to group observations or variables into clusters based on the high similarity of climatologic features, where the input data matrix consisted of the stations as variables and the number of hail days in pentads of warm season being the cases. The stations were divided according to their Euclidean distance between them, which is visualised as a tree diagram (Fig. 2). As a result, three groups of stations were created. The analysis of the spatial distribution of the stations in each group allowed distinguishing five separate hail regions in central Europe. This method of clustering has proved to be widely used in climatology, for instance to determine thunderstorm, snow or rainfall regions (Kolendowicz 2006, Modarres 2006, Bednorz 2008), types of atmospheric circulation (Bednorz 2008, Suwała 2012) and possibly, climate regions in accordance with various climatic components (Arbabi 2011). Each of the spe- cific clusters of stations was described by some general characteristics, such as the number of stations, the mean number of hail days per station or the hail-peak month.

Furthermore, synoptic conditions of hail occurrence at each cluster of stations were determined. For that purpose we used daily mean sea level pressure (SLP), 500-hPa geopotential height $(500 \mathrm{gh})$ and temperature at the level of 850 and $500 \mathrm{hPa}$ (T850, T500), obtained from the National Centers for Environmental Predictions (NCEP) - National Center for Atmospheric Research (NCAR) reanalysis (Kalnay et al. 1996). The composite maps of SLP and $500 \mathrm{gh}$ encompass the region $35-70^{\circ} \mathrm{N}$ latitude by $35^{\circ} \mathrm{W}-40^{\circ} \mathrm{E}$ longitude with $5^{\circ}$ resolution. Additionally, in order to indicate the differences between the synoptic conditions during the days with hail and seasonal means (April-September) anomalies of the parameters described above were computed. Similar maps, covering a smaller sector of central Europe $\left(65-40^{\circ} \mathrm{N}\right.$ by $0-35^{\circ} \mathrm{E}$ on a $2.5^{\circ} \times 2.5^{\circ}$ grid), 


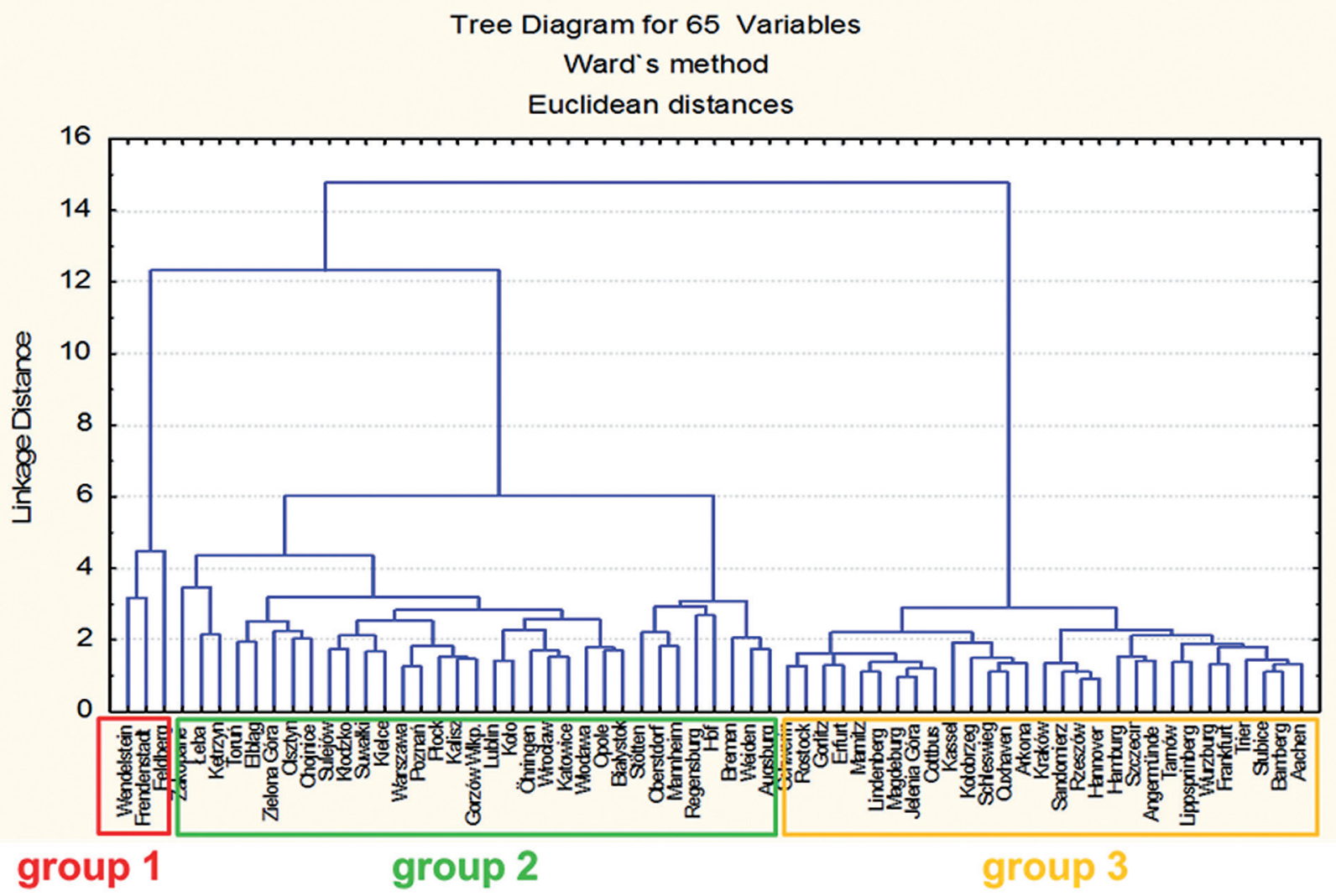

Fig. 2. Groups/clusters of stations distinguished by using the Ward method

were prepared to study horizontal temperature gradient on both levels.

\section{Results}

\subsection{Spatial and temporal variability of hail}

Although hail is widely recognised as a very local, rare and short-term phenomenon over central parts of Europe, some temporal and spatial characteristics can be identified. First and foremost, during the years 1966-2010, 3148 hail events were reported, $65 \%$ of which occurred during the first half of the warm season (April
- June), with May as hail peak month. The mean monthly number of hail days in this multi-year ranged from 4.5 day in September to 15.3 days in May (Table 1).

Considering spatial variability of hail (Fig. 1), the highest number of hail days can be observed in the mountainous, southern part of Germany (more than 75 days during the years 1966-2010), which might be the consequence of land topography, which according to many authors is one of the most significant factors leading to hail precipitation. It may involve the strong friction, enforcing the dynamic turbulence, which speeds up the convective growth of $\mathrm{Cb}$ cloud and the development of convergence zones over the mountains.

Table 1. General characteristics of hail occurrence in central Europe

\begin{tabular}{|c|c|c|c|c|c|c|c|c|}
\hline & \multicolumn{7}{|c|}{ Months } & \multirow{2}{*}{ Apr-Sept } \\
\hline & Apr & May & Jun & Jul & Aug & Sep & Apr-Jun & \\
\hline $\begin{array}{l}\text { 1966-2010 } \\
\text { sum }\end{array}$ & 542 & 842 & 684 & 500 & 334 & 246 & 2068 & 3148 \\
\hline $\begin{array}{l}\text { Seasonal } \\
\text { mean }\end{array}$ & 9.9 & 15.3 & 12.4 & 9.1 & 6.1 & 4.5 & 37.6 & 57.2 \\
\hline Share (\%) & 17.2 & 26.8 & 21.7 & 15.9 & 10.6 & 7.8 & 65.7 & 100.00 \\
\hline
\end{tabular}


At least 50 days with hail were recorded in the lake region in north-eastern Poland, which conforms to the studies of Tuovinen et al. (2009), who claimed that water reservoirs, may stimulate hail formation by providing moisture supplies. In comparison, hail occurred least frequently in the eastern part of the German Lowlands (less than 25 days with hail).

\subsection{Hail regions in central Europe}

Considering the temporal variability of hail occurrence in the pentads of the warm season, different hail regions were distinguished using the Ward's method. In this method, stations with a similar number of hail days and similar hail occurrence's profile in the warm season were clustered in one group. An additional assumption was adopted, which says that a single station cannot create a separate region. As a re- sult, 65 stations were divided into three groups, which show clear spatial distribution that allows dividing the central Europe into separate regions (cluster of stations). Group 2 and 3 included both the stations from Poland and Germany, but due to the spatial distribution of the stations, long distances and considerable climatic differences between the Polish and German sector of central Europe they were treated as separate regions.

Therefore, group 1 corresponds to region 1 , group 2 is represented by region 2 (German stations) and 4 (Polish stations) and similarly group 3 was divided into region 3 (mostly stations from Germany) and 5 (Poland). The final result of this process was to create a map of 5 hail regions in central Europe, which is shown in Figure 3. Region 1, represented by 2 stations, is located in a narrow, mountainous fragment of the Black Forest. The second region, with 9 stations, encompasses the southern part of cen-

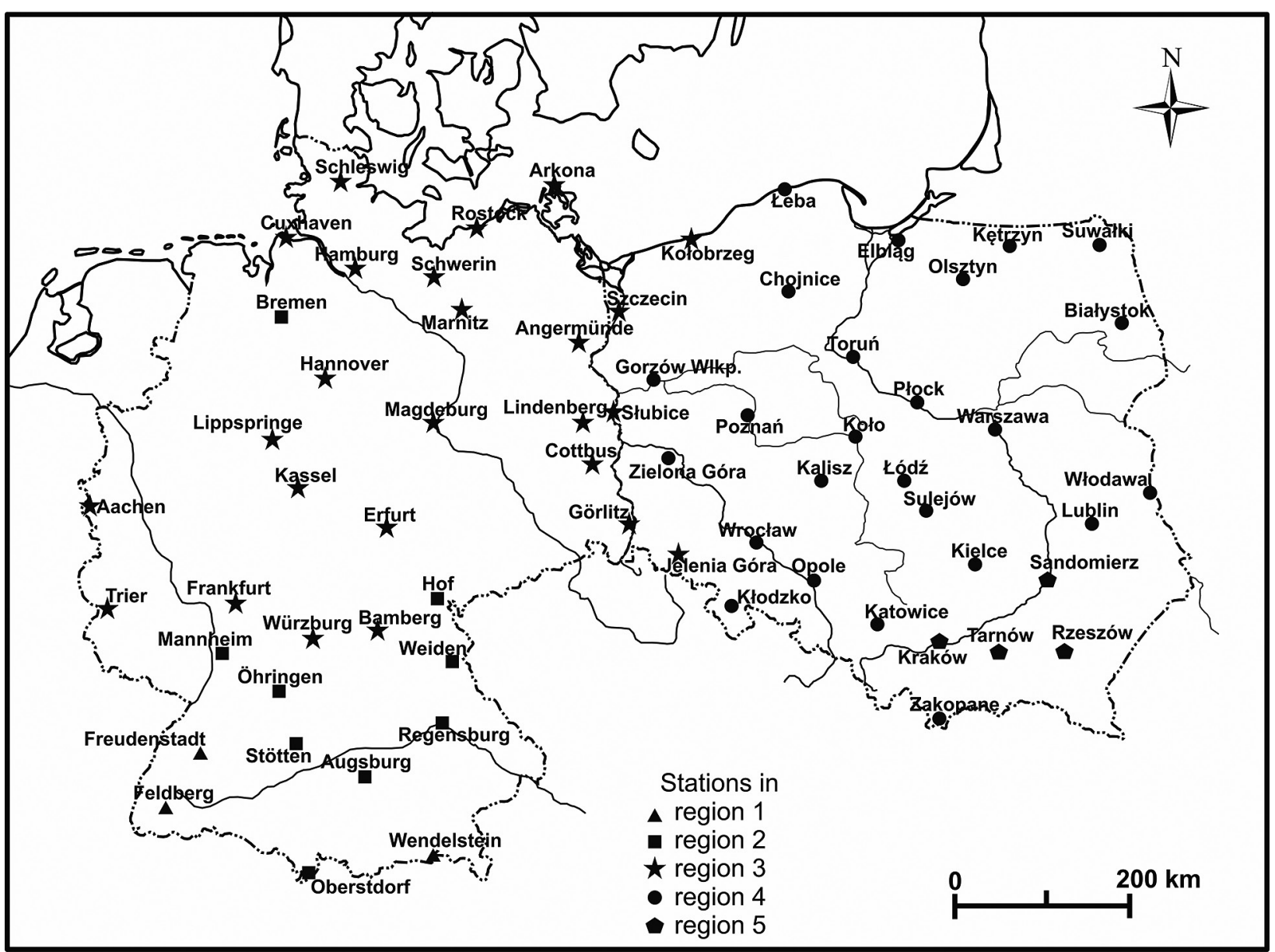

Fig. 3. Hail regions in central Europe according to Ward's method 
Table 2. Mean number of hail days in particular regions averaged for one station for each month and April-September period

\begin{tabular}{|l|c|c|c|r|r|r|r|r|r|}
\hline \multirow{2}{*}{ Regions } & Number & Average & \multicolumn{6}{|c|}{ Mean number of hail days in one station each month } & \multirow{2}{*}{ altitude } \\
\cline { 5 - 8 } & tions & [m a.s.1.] & Apr & May & Jun & Jul & Aug & Sep & \\
\hline Region 1 & 3 & 1373.0 & 8.3 & 34.3 & 33.7 & 26.7 & 22.0 & 5.0 & 130.0 \\
\hline Region 2 & 9 & 468.3 & 4.8 & 11.1 & 12.2 & 10.7 & 5.4 & 2.8 & 47.0 \\
\hline Region 3 & 25 & 123.8 & 3.1 & 5.7 & 5.0 & 4.2 & 3.0 & 1.6 & 22.6 \\
\hline Region 4 & 23 & 172.6 & 8.2 & 10.3 & 7.3 & 5.4 & 3.6 & 3.6 & 38.3 \\
\hline Region 5 & 4 & 212.5 & 4.3 & 7.5 & 5.0 & 3.3 & 2.0 & 1.3 & 23.3 \\
\hline
\end{tabular}

tral uplands to the Alpine foothills. The biggest group of stations (25) formed the third region, which spreads in the North German Lowlands and the northern part of central uplands. It can easily be noticed that the study area is divided into the Polish and German parts. Thus the largest hail region within Poland, consisted of 23 stations, covering almost the entire country, except for the narrow streak along the western boarder and south-eastern uplands and mountains, which created the fifth region consisting of 4 stations. Two stations, Wendelstein and Bremen, were clustered to group 1 and 2 respectively, yet due to their location within different regions they were excluded from the regional analysis.

Concerning regions in terms of the seasonal variability in hail occurrence, it is obvious that they differ from each other. Table 2 compare the regions taking into account the mean number of hail days at one station. The highest number of hail days was recorded in region 1, where from May to August the mean multi-year number of hail days at one station exceeded 20. This is also the region with the highest average altitude of the stations, which is $1373 \mathrm{~m}$ a.s.l. On the other hand, hail appeared least frequently in the lowland part of Germany with 25 stations located at the lowest average altitude, reaching 5.7 days with hail in May. In most regions hail-peak month was May, except for region 2, where the maximum number of hail days occurred in June (12.2). In all regions hail occurred least frequently in September.

\subsection{Atmospheric circulation and the occurrence of hail}

The atmospheric circulation over the Euro-Atlantic sector during the warm half of the year (Fig. 5 - solid lines), from April to September for the years 1966-2010, was formed by two pressure systems situated over the Atlantic, causing a typical zonal flow from west to east. The mean SLP values were the highest $(>1022 \mathrm{hPa}$ ) over the Azores, gradually decreasing towards the Icelandic Low, located south-west of the Iceland $(<1010$ $\mathrm{hPa}$ ). A considerably lower pressure gradient was observed over central and eastern Europe for compared to that over the Atlantic. Therefore the mean $500 \mathrm{hPa}$ geopotential heights declined from the south $(>5800 \mathrm{gpm})$ to the northwest $(<5550$ gpm), which also indicates the western flow in the mid troposphere (Fig. 4 - dashed lines).

For each region, composite maps of the mean and anomalous SLP and $500 \mathrm{hPa}$ geopotential heights were constructed to indicate the characteristic conditions for hail days. The analysis

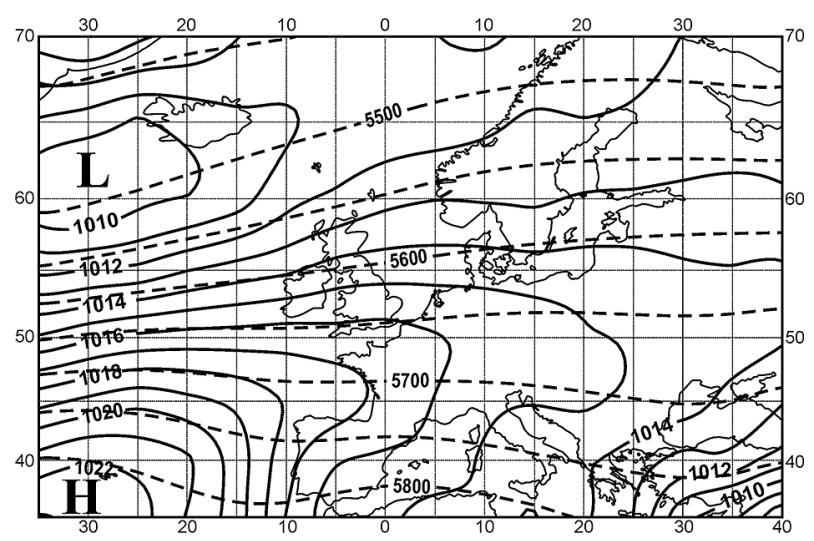

Fig. 4. Mean sea level pressure (solid lines) and geopotential height of $500 \mathrm{hPa}$ (dashed lines) during the warm season (April-September) in the years from 1966 to 2010 
was also supplemented by the picture of anomalous temperature values at 850 and $500 \mathrm{hPa}$, which reveal the differences between the days with and without this phenomenon, giving the additional information about synoptic hail conditions in a larger spatial scale such as the location of colder and warmer air masses in Europe. In general, the circulation conditions favourable for hail precipitation are associated with the negative SLP anomalies and depressions of $500 \mathrm{hPa}$ geopotential heights over the regions or in the vicinity (Fig. 5). In some cases the low pressure system develops over the European continent, but its location varies depending on the region. When it comes to temperature anomalies, each region was characterised by slightly different conditions, although some common features can be observed. In most of the cases the centres of anomalies did not correspond to the location of a region itself, but to a wider area surrounding it. In the mid troposphere negative anomalies were most common in the lowlands, whereas in mountainous regions and uplands they were associated with more complex thermal conditions, which means higher horizontal temperature gradient between eastern and western parts of the region.

In region 1, where hail occurred most often, negative anomalies of SLP were located exactly over the region and they did not overlap with the depression of $500 \mathrm{hPa}$ geopotential heights, which was shifted to the west of Europe, thus indicating the movement of the system towards an easterly direction. At the same time, the $500 \mathrm{hPa}$ geopotential heights over the region were situated up to $20 \mathrm{gpm}$ higher than average. The values of the SLP and $500 \mathrm{hPa}$ geopotential heights anomalies were minor, reaching in their centre $-2 \mathrm{hPa}$ and $-10 \mathrm{gpm}$, respectively. No clear pressure system is visible over the European continent and the horizontal SLP gradient there is rather small, while the arrangement of the isobars suggests slow formation of a surface trough over northern or Eastern Europe. The configuration of $500 \mathrm{hPa}$ geopotential heights over central Europe indicates the presence of a relatively warmer air mass (maximum values over the region - 5700 gpm). As a consequence, the circulation during the days with hail in mountainous parts of Germany covering region 1 was characterized by typical westerlies in the lower parts of the troposphere and additionally by a southern component of influx in the mid troposphere (Fig. 5). What is more, hail precipitation in this region required positive temperature anomalies on both levels. In the lower parts of the troposphere $(850$ $\mathrm{hPa}$ level) the centre of positive anomalies was located over central Europe, indicating the presence of a warmer air mass, as the temperature increased by at least $3^{\circ} \mathrm{C}$ (Fig. 6). In the mid troposphere the growth was not so significant.

Atmospheric circulation conditions during hail precipitation in region 2 were slightly similar to those of region 1 , though in this case it required a vast trough of low pressure over the northern Atlantic sector and a not fully formed anticyclone over the Balkan. The centre of negative SLP anomalies was located slightly north of the region, reaching $-2.5 \mathrm{hPa}$ and it did not correspond to the centre of negative $500 \mathrm{hPa}$ geopotential height anomalies (-30 gpm), which indicates the western flow of the air mass over southern Germany (Fig. 5). The spatial distribution of temperature anomalies on both levels was much more complex than in region 1 , since the central Europe sector was divided into the positive and negative anomalies sectors. In the lower troposphere the $0^{\circ} \mathrm{C}$ value of anomalies run along the western borders of Germany, while in the mid troposphere it was shifted to the east reaching Poland. The highest values of positive anomalies were observed over Poland at the level of $850 \mathrm{hPa}$, where temperature increase of about $1.5^{\circ} \mathrm{C}$ was recorded. In the mid troposphere the study area was divided into a colder western sector and a warmer eastern sector, and such conditions may indicate in both cases the presence of a cold front passing over this part of Europe. At the same time, comparing the spatial distribution and values of the anomalies in the upland (regions 1, 2 and 5) and lowland regions (regions 3 and 4), hail occurrence in a more varied terrain requires stronger anomalies (Fig. 6).

A similar situation accompanied hail precipitation in region 3 , although in this case more significant $\left(-2^{\circ} \mathrm{C}\right)$ negative anomalies of the temperature at $500 \mathrm{hPa}$ levels were observed (Fig. 6). The centre of those negative anomalies in the mid-troposphere was located exactly over the North German Lowlands. At the same time, the highest values of negative SLP $(-3.5 \mathrm{hPa})$ and 

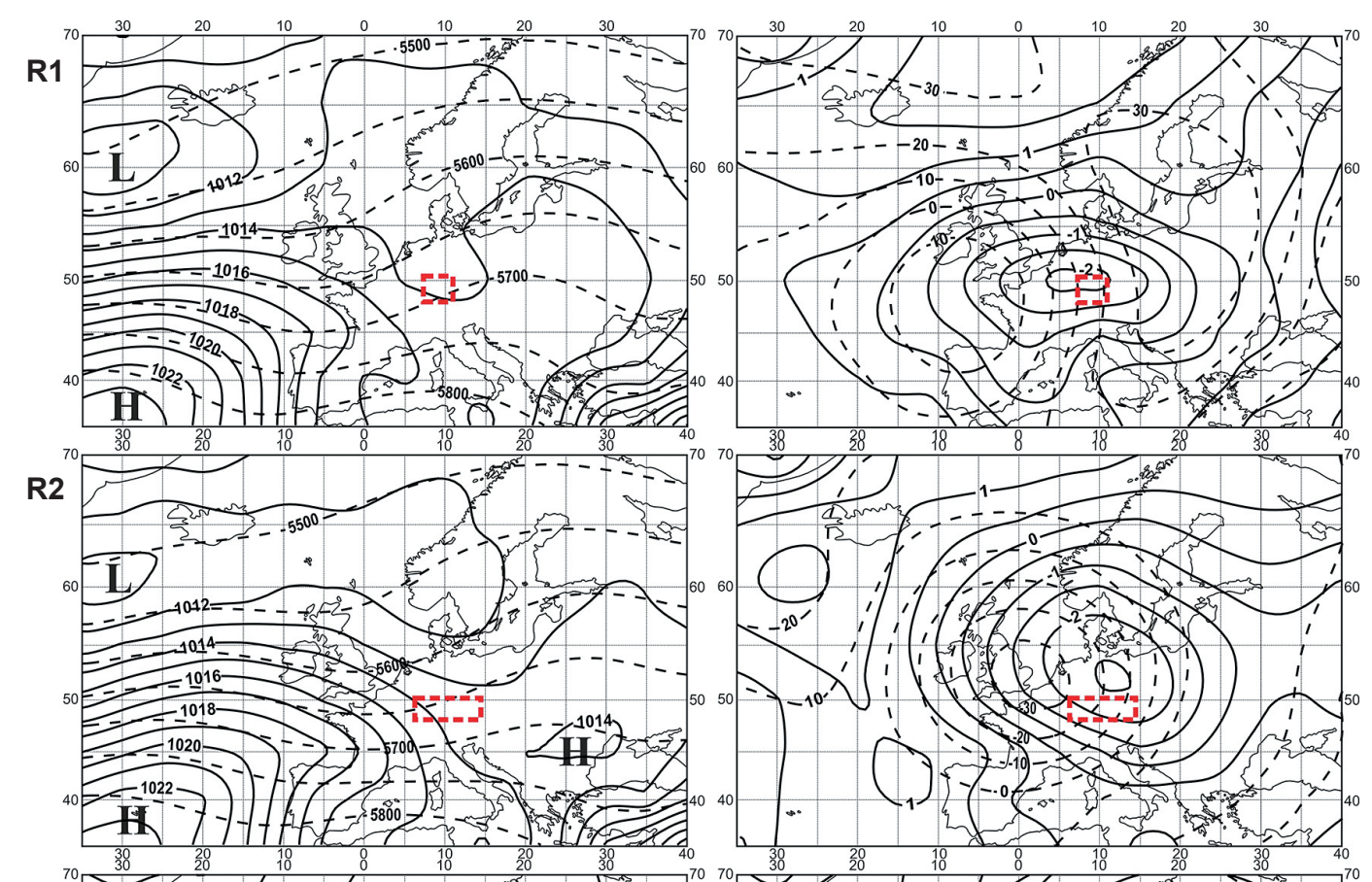

R3
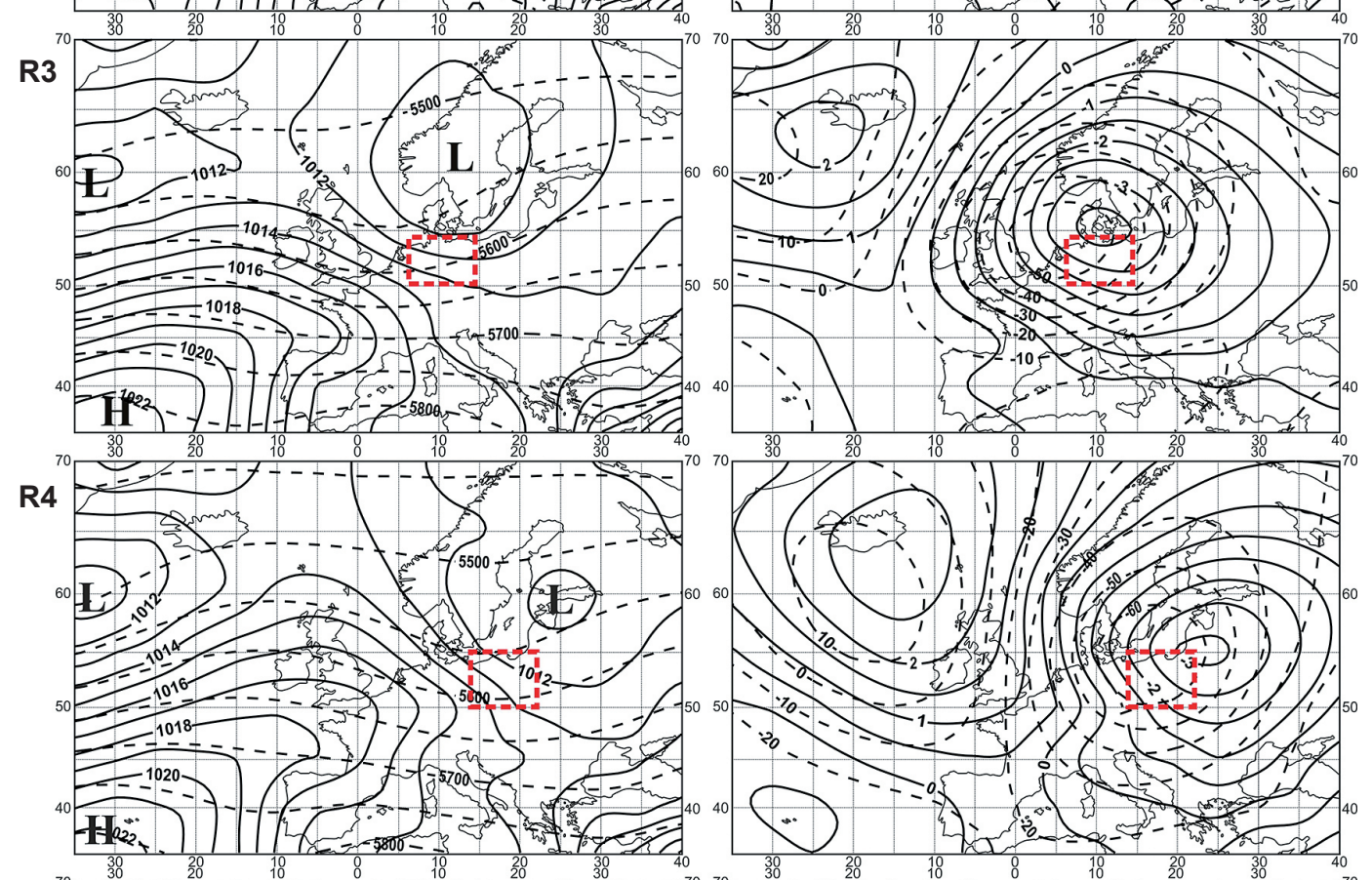

\footnotetext{
R5
}
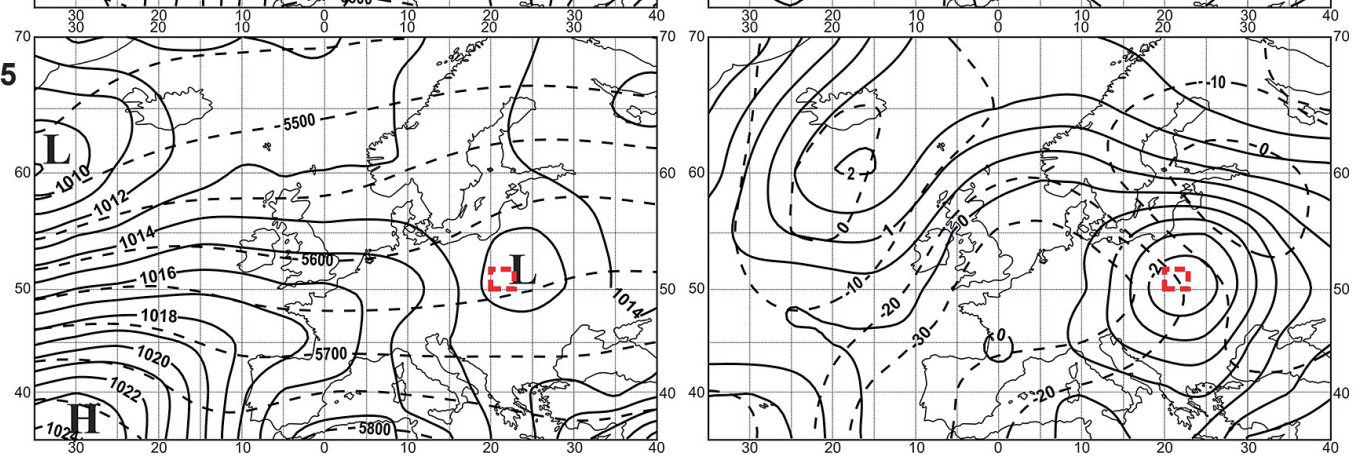

Fig. 5. Mean sea level pressure and geopotential height of $500 \mathrm{hPa}$ (left column) with anomalies (right column) for the days with hail at each cluster of stations (signatures R1 to R5 - each cluster of stations). Rectangle marked with dashed line location of each region 

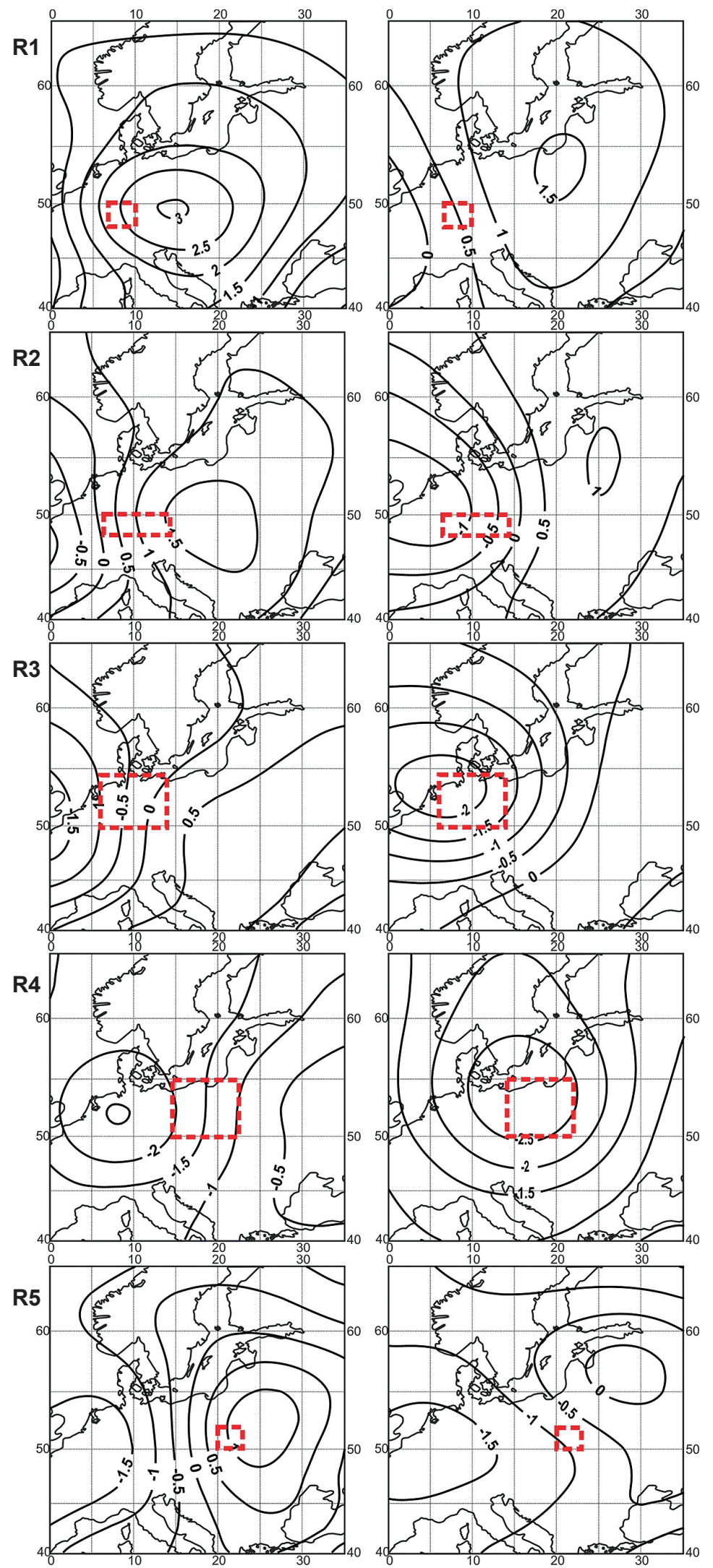

Fig. 6. The anomalies of temperature at $850 \mathrm{hPa}$ (left column) and $500 \mathrm{hPa}$ (right column) during the days with hail at each cluster of stations (signatures R1 to R5 - each cluster of stations). Rectangle marked with dashed line - location of each region 
$500 \mathrm{hPa}$ geopotential height (-50 gpm) anomalies were recorded. In this situation, the centre of both SLP and $500 \mathrm{hPa}$ geopotential height anomalies was located over the region. A low pressure system formed over the Scandinavian Peninsula, causing an influx of cold, polar maritime air masses from the northwest (Fig. 5).

Strong negative anomalies of both parameters (Fig. 5) caused hail precipitation in region 4 . The centres of SLP $(-3 \mathrm{hPa})$ and $500 \mathrm{hPa}$ geopotential height anomalies were located over Poland, with the highest values of $500 \mathrm{hPa}$ geopotential height anomalies of all regions, reaching -60 gpm over the region. In this case, a low pressure centre formed over the Gulf of Riga $(<1011 \mathrm{hPa})$ and consequently a stronger north-western cold air mas influx was possible, which has also been visible in the temperature anomalies in the troposphere. At both levels, the values of the temperature were the lowest of all regions, reaching $-2.5^{\circ} \mathrm{C}$, although the centre of the T850 anomalies was located northeast of Poland (Fig. 6).

Hail occurred least frequently in region 5. In this case the centre of negative anomalies of SLP was located exactly over the region and $500 \mathrm{hPa}$ geopotential heights anomalies divided Europe into a north-eastern part with no anomalies and a south-western part with $-30 \mathrm{gpm}$. At the same time, a shallow low-pressure system formed over the south-eastern parts of Poland, causing hail precipitation (Fig. 5). Hail in this part of Poland was also linked to the most complex thermal conditions of all regions, being similar to the thermal situation in region 2 and 3 as regards the warmer part of eastern Europe with the centre of positive anomalies of the temperature at $850 \mathrm{hPa}$ located exactly over the south-eastern Poland. However, compared to the situations in other regions, the temperature gradient at the level of $850 \mathrm{hPa}$ was larger and it considerably decreased towards the west. In the mid troposphere the values of anomalies decline from north-east to south-west, thus the whole study area is located within negative anomalies (Fig. 6).

\section{Discussion and conclusions}

The motivation for analysing the occurrence of hail in this region of Europe grew from the defi- ciencies of studies and publications, also bearing in mind the fact that this extreme weather event causes multiple damages to agriculture and economy (Leigh 2007). Considering the significant influence of atmospheric circulation on the conditions and processes taking place in the overground layer of the atmosphere, the occurrence of hail was analysed in the context of thermal and baric variability within the mid and lower troposphere. The first conclusions that can be drawn from the above findings are related to the general characteristics of the occurrence of hail in central Europe and can be compared to other studies on this phenomenon. First and foremost, $65 \%$ of hail events occurred in the first half of the warm season, which was previously observed in Poland, the North German Lowlands (Bielec-Bąkowska 2010, Suwała 2012) but also in the north and western sector of China (Zhang et al. 2008). The month in which hail occurred most often was May, which corresponds to some recent research in this region (Bielec-Bakowska 2010), but it is contrary to the results from the mid-60s. (Zinkiewicz, Michna 1955, Koźmiński 1964) when hailpeak month appeared in June or July. Comparing it to the results for Finland (July) (Tuovinen et al. 2009) the hail-peak month was shifted to the earlier months of the warm half-year, but it was more similar to the situation in northern Greece (Sioutas et al. 2009). It was also proved that the spatial distribution of hail is strongly related to the land topography as the highest number of hail events during the years 1966-2010 was recorded in the mountainous, southern part of Germany (region 1) with May being the hail-peak month, and in the north-eastern lake region. This privileging of upland areas might be associated with the shorter positive buoyancy. The terrain-related distribution of hail frequency was also visible in the regionalisation. Concurrently, hail occurred least frequently in the North German Lowlands and the south-eastern part of Poland.

In this analysis clustering data and distinguishing hail regions were based on the Ward's method. Another approach to regionalisation was suggested by Zhang et al. (2008), which involved distinguishing the hail-peak month in each station. Although that method was also tested for this study and the results corresponded to the Ward's regionalization, eventually it was 
decided that the statistical method will be more objective. This approach in the studies on hail can be used as an introduction to some further discussion on severe weather phenomena. It definitely proves that hail is characterised by some spatial and temporal variability that enables distinguishing between different hail regions which, according to Zhang et al. (2008), improves the more detailed analysis and indicates the differences within larger taxonomic units.

As far as the atmospheric circulation is concerned, it was found that the most typical conditions for hail occurrence in central Europe are the negative anomalies of the sea level pressure and the depression of 500-hPa geopotential heights over the European continent, usually with a low pressure system and the disturbance in zonal influx. All the same, the necessity of regional divisions in climatology is confirmed by the variation of the atmospheric circulation conditions specified for each region as the location and intensity of the anomalies may differ. However, the biggest difference between all five regions was noticeable in the thermal conditions which were much more complex and varied spatially. As it was previously mentioned, five hail regions can be distinguished, in which hail precipitation involved the following atmospheric conditions:

1) Hail in mountainous region 1 can be associated with the less negative sea level pressure anomalies and no distinct pressure system over Europe. The positive anomalies of 500$\mathrm{hPa}$ geopotential height and the temperature at 850 and $500 \mathrm{hPa}$ indicate that a warmer air mass was located over the region. The remaining part of the German uplands, marked as region 2, was within the negative anomalies of both the sea level pressure and the 500-hPa geopotential height, but their centres were at a considerable distance indicating the dynamic movement of the pressure system to the west, which is also visible in the thermal condition in the troposphere, evidencing the passage of a cold front with the positive anomalies over eastern Europe. These results correspond to the observations of Kunz et al. (2009), which have proven that hail in southern Germany can be caused by either a higher pressure over central Europe or a low with fronts in the northern sector of Europe.
2) The lowland part of the research area (regions 3 and 4) owed the hail precipitation to the presence of a more distinct low pressure system over the Scandinavian part of Europe and, more importantly, to the strong negative sea level pressure and $500-\mathrm{hPa}$ geopotential height anomalies. The centres of the anomalies do not coincide which implies the eastern direction of movement of the pressure system. Generally, hail in this part of central Europe was accompanied by the presence of colder air mass than usual, especially in the mid troposphere, where temperature was lower than average by about $-2^{\circ} \mathrm{C}$. More complex conditions, though, prevailed at the level of $850 \mathrm{hPa}$, indicating the differences between German and Polish sectors. The spatial distribution of temperature anomalies in region 3 may suggest the cold front passing over central Europe, whereas hail in Poland is related to strong negative anomalies $\left(-2.5^{\circ} \mathrm{C}\right)$. The differences might be explained by the contribution of air mass characteristics to the climatic changes at each cluster of stations (fresh polar maritime air mass over Germany).

3) Region 5 was characterised by the most clear baric situation with a shallow low pressure system and the centre of negative SLP anomalies over the south-eastern part of Poland. Both the anomalies of the mid troposphere geopotential height and the temperature suggest the drop in temperature towards the southwest. Similarly to regions 2 and 3, the temperature distribution in the lower troposphere indicates the colder air mass influx with the passage of the cold front.

\section{Acknowledgements}

This research was supported by the Grant for Scientific Research of National Science Centre: N/ST10/04780 ("The influence of the atmospheric circulation on the occurrence of hail in Poland and selected countries of the Central Europe in the years 1971-2010"), project leader: Katarzyna Suwała, carried out at Adam Mickiewicz University. We acknowledge staff at IMGW PIB and Deutscher Wetterdienst for supporting this study with their data-bases. Special acknowledgement 
goes to NOAA/OAR/ESRL PSD, Boulder, Colorado, USA for providing NCEP Reanalysis data (http://www.esrl.noaa.gov/psd/).

\section{References}

Arbabi A., 2011. Cluster-based method for understanding the climactic diversity of Iran. African Journal of Agricultural Research 6(31): 6525-6529.

Bednorz E., 2008. Synoptic reasons for heavy snowfalls in the Polish-German lowlands. Theoretical and Applied Climatology 92: 133-140.

Bielec-Bąkowska Z., 2010. Występowanie gradu w Polsce w świetle cyrkulacji atmosfery w latach 1966-2006. Woda w badaniach geograficznych: 359-374.

Changnon S.A., Changnon D., Hilberg S.D., 2009. Hailstorms across the nation. An atlas about hail and its damages. Illinois State Water Survey.

Groenemeijer P.H., van Delden A., 2006. Sounding-derived parameters associated with large hail and tornadoes in the Netherlands. Atmospheric Research 83: 473-487.

Hohl R., Schweingruber F.H., Schiesser H.-H., 2002. Reconstruction of severe hailstorm occurrence with tree rings: a case study in central Switzerland. Tree-ring Research 58(1/2): 11-22.

Kalnay E., Kanamitsu M., Kistler R., Collins W., Deaven D., Gandin L., Iredell M., Saha S., White G., Woollen J., Zhu Y., Chelliah M., Ebisuzaki W., Higgins W., Janowiak J., Mo K.C., Ropelewski C., Wang J., Leetmaa L., Reynolds R., Jenne R., Joseph D., 1996. The NMC/NCAR 40-Year Reanalysis Project. Bulletin of American Meteorological Society 77: 437-471.

Kapsch M.-L., Kunz M., Vitolo R., Economou T., 2012. Long-term trends of hail-related weather types in an ensemble of regional climate models using a Baessian approach. Journal of Geophysical Research 117. DOI: 10.1029/2011JD017185.

Kolendowicz L., 2006. The influence of the synoptic situations on the occurrence of days with thunderstorms during a year in the territory of Poland. International Journal of Climatology 26: 1803-1820.
Koźmiński Cz., 1964. Geograficzne rozmieszczenie większych burz gradowych zanotowanych na obszarze Polski w latach 1946-1956. Przeglad Geograficzny 36(1): 87-102.

Kunz M., Sander J., Kottmeier Ch., 2009. Recent trends of thunderstorm and hailstorm frequency and their relation to atmospheric characteristics in southwest Germany. International Journal of Climatology 29: 2283-2297.

Leigh R., 2007. Hail storm-one of the costliest natural hazards. Coastal Cities Natural Disasters Conference, Sydney, 20-21 February.

Modarres R., 2006. Regional precipitation climates of Iran. Journal of Hydrology 45(1): 13-27.

Niall S., Walsh K., 2005. The impact of climate change on hailstorms in southeastern Australia. International Journal of Climatology 25: 1933-1952.

Piani F., Crisci A., De Chiara G., Maracchi G., Meneguzzo F., 2005. Recent trends and climatic perspective of hailstorms frequency and intensity in Tuscany and Central Italy. Natural Hazards and Earth System Sciences 5: 217-224.

Simeonov P., Georgiev C.G., 2003. Severe wind/hail storms over Bulgaria in 1999-2001 period: synoptic- and meso-scale factors for generation. Atmospheric Research 67: 629-643.

Sioutas M.V., Flocas H.A., 2003. Hailstorms in Northern Greece: synoptic patterns and thermodynamic environment. Theoretical and Applied Climatology 75: 189-202.

Sioutas M.V., Meaden T., Webb J.D.C., 2009. Hail frequency and intensity in northern Greece. Atmospheric Research 93: 526-533.

Suwała K., 2012. The influence of atmospheric circulation on the occurrence of hail in the North German Lowlands. Theoretical and Applied Climatology. DOI: 10.1007/s00704012-0735-6.

Svabik O., 1989. Review of meteorological aspects on hail defense activities in Austria. Theoretical and Applied Climatology 40: 247-254.

Tuovinen J.-P., Punkka A.-J., Rauhala J., Hohti H., Schultz D.M., 2009. Climatology of Severe Hail in Finland: 19302006. Monthly Weather Review 137(7): 2238-2249.

Zhang C., Zhang Q., Wang Y., 2008. Climatology of hail in China: 1961-2005. Journal of Applied Meteorology and Climatology 47: 795-804.

Zienkiewicz W., Michna E., 1955. Częstotliwość występowania gradów w województwie lubelskim $\mathrm{w}$ zależności od warunków fizjograficznych. Annales UMCS Sectio B, 10 (5): 223-300. 